\title{
SEMANTIK DAN APLIKASINYA PADA STRUKTUR KALIMAT DALAM BAHASA JAWA DI DESA SRIMULYO KECAMATAN BELITANG MULYA
}

\author{
Beti Wijayanti $^{1^{\star}}$, Chindyana Laurica ${ }^{2}$, Khoirun Nisa ${ }^{3}$ \\ Program Studi Pendidikan Bahasa dan Sastra Indonesia \\ STKIP Nurul Huda OKU Timur
}

\begin{abstract}
Abstrak
Masalah dalam penelitian ini adalah apakah semantik dan aplikasinya telah diterapkan dengan baik pada struktur kalimat dalam bahasa Jawa di Desa Srimulyo Kecamatan Belitang Mulya Kabupaten OKU Timur. Tujuan penelitian ini adalah untuk menginformasikan kepada masyarakat Desa Srimulyo mengenai makna verba beserta aplikasinya dalam sebuah kalimat yang dilihat dari kajian semantiknya. Semantik adalah cabang ilmu linguistik yang mempelajari tentang makna, ada banyak manfaat yang dapat diperoleh dari mempelajari semantik dan setiap kata yang kita ucapkan atau kita dengar memiliki makna. Manfaat penelitian ini adalah untuk mengetahui dan mendeskipsikan semantik dan aplikasinya pada struktur kalimat dalam bahasa Jawa di Desa Srimulyo Kecamatan Belitang Mulya. Penelitian ini juga diharapkan dapat bermanfaat bagi pembaca dan peneliti lainnya. Metode yang digunakan dalam penelitian ini adalah metode deskriptif. Teknik pengumpulan data yang digunakan dalam penelitian ini adalah teknik observasi, teknik wawancara, teknik rekam, dan teknik catat. Sumber data dalam penelitian ini diperoleh dengan mewawancarai delapan informan yang mewakili status sosial yang ada di Daerah Srimulyo. Hasil analisis bertumpu pada kata kerja dan kalimat. Jenis verba dibagi menjadi tiga, yaitu makna verba berafiks, makna reduplikasi verba, dan makna komposisi verba. Makna verba berafiks berjumlah tujuh, makna reduplikasi verba berjumlah enam, dan makna komposisi verba berjumlah dua.
\end{abstract}

Kata Kunci: Semantik, bahasa Jawa, dan struktur kalimat.

\section{PENDAHULUAN}

Semantik merupakan cabang ilmu linguistik yang mempelajari tentang arti kata atau makna. Bahasa merupakan alat berinteraksi atau berkomunikasi yang digunakan manusia untuk menyampaikan pikiran, gagasan, konsep atau juga perasaan, bahasa juga sebagai alat komunikasi yang didayagunakan untuk menyampaikan pesan kepada orang lain dengan harapan apa yang telah disampaikan bisa dipahami dan dimengerti oleh orang tersebut (Chaer, 2011: 1). Semantik dalam bahasa Indonesia berasal dari bahasa Yunani yaitu sema kelas kata benda yang berarti "tanda" atau "lambang". Kelas kata kerjanya yaitu semaino yang bermakna "menandai" atau "melambangkan" (Chaer, 2009: 2). Semantik salah satu cabang ilmu linguistik yang memiliki kaitan erat dengan ilmu-ilmu sosial seperti sosiologi, antropologi, filsafat, dan psikologi.

Bangsa Indonesia merupakan negara kepulauan yang terdiri atas etnik. Tiap-tiap etnik memiliki bahasa daerahnya masing-masing sebagai identitas kelompok. Indonesia adalah negara yang multilingual. Selain bahasa Indonesia yang digunakan secara nasional, terdapat pula berbagai bahasa daerah, besar maupun kecil yang digunakan oleh masyarakat bahasa daerah tertentu untuk keperluan yang bersifat kedaerahan (Chaer, 2009: 65). Bahasa memegang peranan penting dalam kehidupan manusia. Hal ini harus benar-benar disadari. Terutama dalam keanekaragaman bahasa di Indonesia yang begitu banyak. Keragaman bahasa inilah yang menyebabkan situasi sosiolinguistik di Indonesia menjadi bervariasi. Ini terjadi karena Indonesia adalah salah satu negara yang kaya akan suku budaya serta bahasanya, salah satunya adalah bahasa Jawa.

Bahasa Jawa adalah bahasa yang digunakan oleh penduduk bersuku bangsa Jawa yang berada daerah di Jawa Tengah, Yogyakarta, dan Jawa Timur. Selain itu, bahasa Jawa juga digunakan oleh penduduk di beberapa daerah lain seperti Banten (terutama Serang, Cilegon, dan Tanggerang) serta Jawa Barat (terutama kawasan pantai utara yang meliputi Karawang, Subang, Indramayu, dan Cirebon). Sementara mayoritas masyarakat Belitang terutama di Desa Srimulyo bersuku Jawa karena masyarakat Belitang adalah transmigran dari Jogyakarta dan sekitar daerah Jawa Tengah, otomatis bahasa yang 
digunakan adalah bahasa Jawa. Masyarakat Desa Srimulyo sehari-harinya menggunakan bahasa Jawa untuk berinteraksi dengan orang lain. Bahasa Jawa merupakan salah satu bahasa daerah yang sampai saat ini masih digunakan di Indonesia terutama oleh masyarakat Jawa khususnya di Kecamatan Belitang Mulya Kelurahan Srimulyo. Sebagai bahasa daerah yang berada di Indonesia, hendaknya bahasa Jawa harus dilestarikan. Contoh bahasa Jawa antara lain /lara/ (sakit), /watu/ (batu), dan lain-lain.

Peneliti akan membatasi penggunaan semantik dalam penelitiannya, yakni semantik yang diaplikasikan pada komunikasi sehari-hari masyarakat Desa Srimulyo Kecamatan Belitang Mulya Kabupaten OKU Timur. Hal tersebut dikarenakan penggunaan semantik dalam kegiatan ekonomi di daerah Srimulyo Kecamatan Belitang Mulya masih kurang digunakan. Dilihat dari kata kerja dan berbagai aplikasinya itu sendiri berupa perfiks (awalan), sufiks (akhiran), dan penggabungan, maka dalam bahasa Jawa dan berbagai aplikasinya tersebut akan terjadi perubahan penulisan serta lafal dalam suatu kalimat dalam bahasa Jawa.

Semantik merupakan cabang ilmu bahasa yang membahas hubungan antara tanda-tanda linguistik dengan hal-hal yang ditandainya. Semantik juga merupakan cabang ilmu bahasa yang membahas tentang makna yang meliputi aspek struktur dan fungsi bahasa. Secara umum semantik lazim diartikan sebagai kajian mengenai makna bahasa. Mengapa, karena dalam kehidupan banyak makna yang tidak berkaitan dengan bahasa, melainkan dengan tanda-tanda dan lambang-lambang lain, seperti tanda lalu lintas, tanda kejadian alam, lambang-lambang Negara dan lain-lain (Chaer, 2007: 67).

\section{METODE PENELITIAN}

Metode penelitian pada dasarnya merupakan cara ilmiah untuk mendapatkan data dengan tujuan dan kegunaan tertentu. Berdasarkan hal tersebut terdapat empat kata kunci yang perlu diperhatikan yaitu, cara ilmiah, data, tujuan, dan kegunaan (Sugiyono, 2016: 2). Metode penelitian adalah suatu proses atau cara ilmiah untuk mendapatkan data yang akan digunakan untuk penelitian (HfsBot, 2017). Metode penelitian kualitatif adalah metode yang berlandaskan pada filsafat postpositivisme, penelitian ini digunakan untuk meneliti pada kondisi objek yang alamiah, (sebagai lawannya adalah metode penelitian eksperimen) di mana peneliti sebagai sarana penelitian, pengambilan data, sumber data dilakukan dengan cara purposive dan snowball, teknik pengumpulan data dengan trianggulasi, analisis data bersifat induktif/kualitatif, dan hasil penelitian kualitatif lebih menekankan makna dari pada generalisasi. Triangulasi berarti teknik pengumpulan data yang bersifat menggabungkan dari berbagai teknik pengumpulan data dan sumber data yang sudah ada. Dari penjelasan di atas dapat disimpulkan bahwa metode penelitian adalah rencana atau gambaran dari suatu kegiatan yang disusun secara sistematis dan terperinci dengan pada akhirnya akan diikuti dengan realisasi kegiatan itu sendiri (Rakim, Jurnal Metode Penelitian, Tahun 2008 No.06/Februari-September 2008, diakses 5 Mei 2020).

Metode yang digunakan peneliti dalam penelitian ini adalah metode deskriptif. Metode deskriptif adalah suatu metode dalam meneliti setatus sekelompok manusia, suatu obyek, suatu kondisi, suatu sistem pemikiran, ataupun suatu kelas peristiwa pada masa sekarang. Tujuan dari penelitian deskriptif ini adalah untuk membuat deskipsi, gambaran atau melukiskan secara sistematis, faktual dan akurat mengenai fakta-fakta, sifat-sifat serta hubungan antar fenomena yang diselidiki (Addhintheas, Metode Penelitian Deskriptif, Tahun 2013 No 04/Juni- Oktober 2013, diakses 5 Mei 2020). Penulis menggunakan metode deskriptif dalam penelitian ini bertujuan untuk mendeskripsikan semantik dan aplikasinya pada struktur kalimat dalam bahasa Jawa di Desa Srimulyo Kecamatan Belitang Mulya. Teknik yang akan dilakukan oleh penulis dalam penelitian ini ada empat cara yaitu teknik observasi, teknik wawancara, teknik rekam, dan teknik catat.

Masalah yang dihadapi oleh peneliti kualitatif adalah apakah temuan yang dihasilkan telah lengkap dan apakah penemuan tersebut dapat dikonfirmasikan reliabitasnya dan validitasnya. Peneliti kualitatif menyusuri latar penelitian untuk menemukan data yang jenisnya beragam dan setiap jenis jumlanya sangat banyak. Untuk memastikan data/informasi lengkap, validitas, dan rehablitasnya tinggi peneliti kualitatif mempergunakan teknik triangulasi. Trianggulasi dalam pengujian kredibilitas ini diartikan sebagai pengecekan data dari berbagai sumber dengan berbagai cara, dan berbagai waktu.

Beti Wijayanti, Chindyana Laurica, Khoirun Nisa 
SEMANTIK DAN APLIKASINYA PADA STRUKTUR KALIMAT ... 35

Trianggualasi adalah suatu pendekatan riset yang memakai suatu kombinasi lebih dari satu strategi dalam satu penelitian untuk mendapatkan data ataupun informasi. Teknik trianggualasi yang dapat digunakan ada tiga yaitu, trianggulasi sumber, trianggulasi teknik, dan trianggulasi waktu. Teknik analisis data adalah cara menguraikan dan menyatukan satuan lingual sesuai dengan pola-pola, tematema, kategori-kategori, kaidah-kaidah, dan masalah-masalah penelitian (Muhammad, 2011: 233). Analisis data merupakan upaya yang diakukan untuk mengklasifikasikan atau mengelompokkan data, pada tahap ini dilakukan upaya mengelompokkan, menyamakan data yang sama dan membedakan data yang memang berbeda serta menyisihkan pada kelompok lain data yang serupa, tetapi tidak sama.

Dengan kata lain pada tahap ini dilakukan pemilihan data yang diperlukan atau tidak diperlukan. Memiliki dua wujud, yaitu data yang berwujud angka (kuantitatif) dan data yang berwujud bukan angka (kualitatif) (Mahsun, 2011: 254). Dilihat dari wujud data tersebut, penelitian ini merupakan penelitian bidang kebahasaan yang bersifat deskriptif, maka wujud atau jenis data yang digunakan adalah data kualitatif. Karena penelitian ini berkaitan dengan data kualitatif maka data yang sudah terkumpul kemudian dianalisis dengan menggunakan analisis kualitatif yaitu data yang dianalisis dalam bentuk kata-kata bukan angka (Mahsun, 2011: 257). Teknik yang digunakan dalam penelitian ini adalah teknik lesap (delection) sebagai salah satu teknik dalam analisis data. Pembuktiannya dilakukan dengan cara melesapkan unsur (ter-) pada kedua bentuk ini sehingga diperoleh bentuk lampau dan lanjur (sebagai data tambahan pemiringan analisis). Bentuk lampau dikatakan sebagai morfem dasar, karena meskipun tanpa unsur (ter-), tetap merupakan unsur yang berterima, berbeda dengan lanjur yang tidak terterima setelah unsur (ter-) dilesapkan (Mahsun, 2011: 107).

\section{HASIL DAN PEMBAHASAN}

\section{Hasil Penelitian}

Berdasarkan hasil penelitian mengenai verba atau kata kerja dalam bahasa Jawa di Kecamatan Belitang Mulya Desa Srimulyo dari data yang didapat melalui observasi, wawancara, rekaman, dan catat, maka diperoleh data mengenai verba atau kata kerja dalam bahasa Jawa di Kecamatan Belitang Mulya Desa Srimulyo yang mencakup seratus kata kerja dan lima puluh kalimat menggunakan kata kerja yang diambil dari bahasa Indonesia.

\section{Proses Verba Bahasa Jawa \\ Makna Verba Berafiks \\ Makna Verba Prefiks Me-}

(1) Menyatakan makna berbuat seperti yang tersebut pada bentuk dasar.

Adek ijek belajar nules.

(Adik sedang belajar menulis)

Kata dasar menulis adalah tulis, tetapi dalam bahasa Jawa tulis berarti /nule's/ berarti di sini telah terjadi pelesapan kata dari tulis menjadi /nule's/.

Adek nanges mergo ceblok.

(Adik menangis karena terjatuh)

Kata dasar menangis adalah tangis, tetapi dalam bahasa Jawa tangis berarti /nange's/ berarti di sini telah terjadi pelesapan kata dari tangis menjadi /nange's/.

Deskripsi makna leksikal dan makna gramatikal pada kata kerja menulis dan menangis dalam penelitian ini sebagai berikut.

Pada kata kerja menulis dan menangis mempunyai makna dan fungsi, kata kerja menulis dan menangis berarti berhungan dengan suatu perbuatan. 
(2) Menyatakan makna membuat seperti yang tersebut pada bentuk dasar.

Sopo seng mbubrah omah kae?

(Siapa yang membongkar rumah itu?)

Kata dasar membongkar adalah bongkar, tetapi dalah bahasa Jawa berarti /mbrubah/maka di sini telah terjadi pelesapan kata dari bongkar menjadi /mbrubah/.

Adek ijek ngerangkai macem-macem bentuk kembang.

(Adik sedang merangkai berbagai bentuk bunga)

Kata dasar merangkai adalah rangkai, sedangkan dalam bahasa Jawa berarti /ngrangka'i/ itu tandanya telah terjadi pelesapan kata dari kata rangkai menjadi /ngrangka'i/.

Deskripsi makna leksikal dan makna gramatikal pada kata kerja memasak dan merangkai dalam penelitian ini sebagai berikut.

Pada kata kerja memasak dan merangkai mempunyai makna dan fungsi, kata kerja memasak dan merangkai berarti berhubungan dengan sesuatu yang membuat.

\section{Makna Verba Prefiks Ber-}

(1) Menyatakan bahwa berbuat seperti yang tersebut pada bentuk dasar.

Tikus kae mlayu dikejar kuceng.

(Tikus itu berlari dikejar kucing)

Kata dasar berlari adalah lari, namun dalam bahasa Jawa lari berari mlayu. Berarti di sini telah terjadi pelesapan kata dari lari menjadi /mblayu/.

Manuk perkutut suit-siut mben isuk.

(Burung perkutut bersiul setiap pagi)

Kata dasar bersiul adalah siul, namun dalam bahasa Jawa berarti /suit-siut/. Berarti dalam kata bersiul telah terjadi pelesepan kata dari kata bersiul menjadi /suit-suit/.

Deskripsi makna leksikal dan makna gramatikal pada kata kerja berlari dan bersiul dalam penelitian ini sebagai berikut.

Pada kata kerja berlari dan bersiul mempunyai makna dan fungsi, kata kerja berlari dan bersiul berarti berhubungan dengan sesuatu yang berbuat.

(2) Menyatakan makna memakai atau mengendarai.

Bapak lungo kerjo nompak montor.

(Ayah pergi kerja bermotor)

Kata dasar bermotor adalah motor. Namun, dalam bahasa Jawa bermotor berarti nompak montor. Ini berarti telah terjadi pelesapan kata dari ber-menjadi /nompak/.

Mamak lungo neng pasar nompak pedah.

(Ibu pergi ke pasar bersepeda)

Kata dasar bersepeda adalah sepeda. Namun, dalam bahasa Jawa bersepeda berarti nompak pedah. Ini berarti telah terjadi pelesapan kata dari ber-menjadi /nompak/.

Deskripsi makna leksikal dan makna gramatikal pada kata kerja bermotor dan bersepeda dalam penelitian ini sebagai berikut.

Pada kata kerja bermotor dan bersepeda mempunyai makna dan fungsi, kata kerja bermotor dan bersepeda berarti berhubungan dengan sesuatu yang memakai atau mengendarai.

\section{Makna Verba Prefiks Ter-}

(1) Menyatakan makna ketidaksengajaan.

Klambi kenter kegowo arus kali.

(Baju hanyut terbawa arus sungai)

Beti Wijayanti, Chindyana Laurica, Khoirun Nisa 
Tanganku kecucuk eri.

(Tanganku tertusuk duri)

Deskripsi makna leksikal dan makna gramatikal pada kata kerja terbawa dan tertusuk dalam penelitian ini sebagai berikut.

Pada kata kerja terbawa dan tertusuk berarti berhubungan dengan makna ketidaksengajaan.

(2) Menyatakan makna ketiba-tibaan.

Aku turu neng pangkuan mamak.

(Saya tidur di pangkuan ibu)

Pas dikejar asu/kirek aku mencolot tembok duwur e sak meter.

(Ketika dikejar anjing saya terlompat tembok setinggi 1 meter)

Deskripsi makna leksikal dan makna gramtikal pada kata kerja dipangkuan dan terlompat dalam penelitian ini sebagai berikut.

Pada kata kerja dipangkuan dan terlompat mempunyai maknka dan fungsi, kata kerja dipangkuan dan terlompat berarti berhubungan dengan makna ketiba-tibaan.

\section{Makna Verba Prefiks Di-}

Menyatakan makna perbuatan yang pasif.

Rambut adek ditali men rapi.

(Rambut adik diikat supaya rapi)

Pekarangan omah disapu mamak.

(Halaman rumah disapu ibu)

Deskripsi makna leksikal dan makna gramatikal pada kata kerja diikat dan disapu dalam penelitian ini sebagai berikut.

Pada kata kerja diikat dan disapu mempunyai makna dan fungsi, kata kerja diikat dan disapu berarti berhubungan dengan makna perbuatan yang pasif.

\section{Makna Verba Gabungan Me-kan}

(1) Menyatakan makna perbuatan.

Adek ijek noto panggon turune.

(Adik sedang merapikan tempat tidurnya)

Pesulap kae ijek mamerke kelincahan e.

(Pesulap itu sedang menontonkan keahliannya)

Deskripsi makna leksikal dan makna gramatikal pada kata kerja merapikan dan menontonkan dalam penelitian ini sebagai berikut.

Pada kata kerja merapikan dan menontonkan mempunyai makna dan fungsi, kata kerja merapikan dan menontonkan berarti berhubungan dengan makna perbuatan.

(2) Menyatakan makna menyebabkan.

Mamak nyilikne seragam adek seng kegeden.

(Ibu mengecilkan seragam adik yang kebesaran)

Mamak ngedohne banyu anget seko adek.

(Ibu menjauhkan_air hangat dari adik)

Deskripsi makna leksikal dan makna gramatikal pada kata kerja mengecilkan dan menjauhkan dalam penelitian ini sebagai beikut.

Pada kata kerja mengecilkan dan menjauhkan mempunyai makna dan fungsi, kata kerja mengecilkan dan menjauhkan berarti berhubungan dengan makna menyebabkan. 


\section{Makna Verba Gabungan Me-i}

(1) Menyatakan makna perbuatan.

Adek njiwiti pipine.

(Adik menyubiti pipinya)

Kuceng nyokot balung.

(Kucing menggigit tulang)

Deskripsi makna leksikal dan makna gramatikal pada kata kerja menyubiti dan menggigit dalam penelitian ini sebagai berikut.

Pada kata kerja menyubiti dan menggigit mempunyai makna dan fungsi, kata kerja menyubiti dan menggigit berarti berhubungan dengan makna perbuatan.

(2) Menyatakan makna memberi.

Lelek ngirimi Dimas duet.

(Paman mengirimi Dimas uang)

Bapak ijek ngendengi kandang pitek.

(Ayah sedang mengatapi kandang ayam)

Deskripsi makna leksikal dan makna gramatikal pada kata kerja mengirim dan mengatapi dalam penelitian ini sebagai berikut.

Pada kata kerja mengirim dan mengatapi mempunyai makna dan fungsi, kata kerja mengirimi dan mengatapi berarti berhubungan dengan makna memberi.

\section{Makna Verba Gabungan Ber-an}

(1) Menyatakan makna saling.

Tangan Giska senggolan pas salaman karo Naufal.

(Tangan Giska bersentuhan saat bersalaman dengan Naufal)

Ambar kenalan karo Rendy.

(Ambar berkenalan dengan Rendy)

Deskripsi makna leksikal dan makna gramatikal pada kata kerja bersentuhan dan berkenalan dalam penelitian ini sebagai berikut.

Pada kata kerja bersentuhan dan berkenalan mempunyai makna dan fungsi, kata kerja bersentuhan dan berkenalan berarti berhubungan dengan makna saling.

(2) Menyatakan makna sama-sama.

Wong kae tetangisan pas ketemu.

(Mereka bertangisan saat bertemu)

Omahe Vika cedekan karo omahe Yuni.

(Rumah Vika berdekatan dengan rumah Yuni)

Deskripsikan makna leksikal dan makna gramatikal pada kata kerja bertangisan dan berdekatan dalam penelitian ini sebagai berikut.

Pada kata kerja bertangisan dan berdekatan mempunyai makna dan fungsi, kata kerja bertangisan dan berdekatan berarti berhubungan dengan makna sama-sama.

\section{Makna Reduplikasi Verba \\ Makna Reduplikasi Bentuk Dasar}

(1) Menyatakan makna perbuatan yang dilakukan dengan santai.

Rizal lunggoh-lunggoh neng taman.

(Rizal duduk-duduk di taman)

Liburan iki dewe mlaku-mlaku neng Jogyakarta.

Beti Wijayanti, Chindyana Laurica, Khoirun Nisa 
Deskripsi makna leksikal dan makna gramatikal pada kata kerja duduk-duduk dan jalanjalan dalam penelitian ini sebagai berikut.

Pada kata kerja duduk-duduk dan jalan-jalan mempunyai makna dan fungsi, kata kerja duduk-duduk dan jalan-jalan berarti berhubungan dengan makna perbuatan yang dilakukan dengan santai.

(2) Menyatakan makna pekerjaan yang dilakukan berulang-ulang.

Mben akhir bulan Dicky pindah-pindah kosan.

(Setiap akhir bulan Dicky pindah-pindah kosan)

Gaweanne njalok-njalok mbendino.

(Pekerjaannya minta-minta setiap hari)

Deskripsi makna leksikal dan makna gramtikal pada kata kerja pindah-pindah dan mintaminta dalam penelitian ini sebagai berikut.

Pada kata kerja pindah-pindah dan minta-minta mempunyai makna dan fungsi, kata kerja pindah-pindah dan minta-minta berarti berhubungan dengan makna pekerjaan yang dilakukan secara berulang-ulang.

\section{Makna Reduplikasi Verba Prefiks Me-}

Menyatakan makna pekerjaan yang dilakukan berulang-ulang.

Bapak ijek mbukak-bukak koran.

(Ayah sedang membuka-buka koran)

Adek ijek nyoret-nyoret buku tules.

(Adik sedang mencoret-coret buku tulis)

Deskripsikan makna leksikal dan makna gramatikal pada kata kerja membuka-buka dan mencoret-coret dalam penelitian ini sebagai berikut.

Pada kata kerja membuka-buka dan mencoret-coret mempunyai makna dan fungsi, kata kerja membuka-buka dan mencoret-coret berarti berhubungan dengan makna pekerjaan yang dilakukan secara berulang-ulang.

\section{Makna Reduplikasi Verba Prefiks Ber-}

Menyatakan makna pekerjaan yang dilakukan dengan santai.

Wong layat mlaku iring-iringan.

(Pelayat berjalan beriring-iring)

Manuk perkutut siul-siul.

(Burung perkutut bersiul-siun)

Deskripsi makna leksikal dan makna gramatikal pada kata kerja beriring-iring dan bersiul-siul dalam penelitian ini sebagai berikut.

Pada kata kerja beringi-iring dan bersiul-siul mempunyai makna dan fungsi, kata kerja beriring-iring dan bersiul-siul berarti berhubungan dengan makna pekerjaan yang dilakukan santai.

\section{Makna Reduplikasi Verba Prefiks ter-}

Menyatakan makna aspek komunikatif.

Rani nguyu-nguyu kesenengan.

(Rani tertawa-tawa kegirangan)

Mamak mringis-mringis pas nonton acara TV.

(lbu tersenyum-senyum saat nonton acara TV)

Deskripsi makna leksikal dan makna gramatikal pada kata kerja tertawa-tawa dan tersenyum-senyum pada penelitian ini sebagai berikut. 
Pada kata kerja tertawa-tawa dan tersenyum-senyum mempunyai makna dan fungsi, kata kerja tertawa-tawa dan tersenyum-senyum berarti berhubungan dengan makna aspek komunikatif.

\section{Makna Reduplikasi Verba Prefiks Di-}

Menyatakan makna pasif terus-menerus dikenai perbuatan.

Rambute mamak ditarek-tarek adek.

(Rambut ibu ditarik-tarik adik)

Rudo roli diputer-puter.

(Roda gerobak diputar-putar)

Deskripsi makna leksikal dan makna gramatikal pada kata kerja ditarik-tarik dan diputarputar dalam penelitian ini sebagai berikut.

Pada kata kerja ditarik-tarik dan diputar-putar mempunyai makna dan fungsi, kata kerja ditarik-tarik dan diputar-putar berarti berhubungan dengan mnakna terus-menerus dikenai perbuatan.

\section{Makna Reduplikasi Verba Gabungan Ber-+-an}

Menyatakan makna saling.

Mamas jiwit-jiwitan pas guyon.

(Kakak bercubit-cubitan saat bercanda)

Penonton desek-desekan nonton konser.

(Penonton berdesak-desakan menyaksikan konser)

Deskripsi makna leksikal dan makna gramatikal pada kata kerja bercubit-cubitan dan berdesak-desakan dalam penelitian ini sebagai berikut.

Pada kata kerja bercubit-cubitan dan berdesak-desakan mempunyai makna dan fungsi, kata kerja bercubit-cubitan dan berdesak-desakan berarti berhubungan dengan makna saling.

\section{Makna Komposisi Verba}

(1) Menyatakan makna sebenarnya.

Mobel kulu-kilir neng dalan aspal.

(Mobil hilir-mudik di jalan raya)

Rini neng Palembang balek-lungo nompak montor.

(Rini ke Palembang pulang-pergi naik motor)

Deskripsi makna leksikal dan makna gramatikal pada kata kerja hilir-mudik dan pulang-pergi dalam penelitian ini sebagai berikut.

Pada kata kerja hilir-mudik dan pulang-pergi mempunyai makna dan fungsi, kata kerja hilirmudik dan pulang-pergi berarti berhubungan dengan makna sebenarnya.

(2) Menyatakan makna kiasan.

Indah mangan ati pas ditinggal lungo karo cowok e.

(Indah makan hati ketika ditinggal pergi oleh pacarnya)

Deskripsi makna leksikal dan makna gramatikal pada kata kerja makan hati dan diambil hati dalam penelitian ini sebagai berikut.

Pada kata kerja makan hati dan diambil hati mempunyai makna dan fungsi, kata kerja makan hati dan diambil hati berarti berhubungan dengan makna kiasan. 
Pembahasan

Berdasarkan hasil penelitian yang telah dilakukan terhadap delapan narasumber dalam bahasa Jawa di Kecamatan Belitang Mulya, Desa Srimulyo dengan bahasa Indonesia maka ditemukan kata dan kalimat sebagai berikut.

\section{a. Daftar kata kerja}

\begin{tabular}{|c|c|c|c|}
\hline $\begin{array}{c}\text { Kata kerja dalam } \\
\text { Bahasa Jawa }\end{array}$ & $\begin{array}{l}\text { Kata kerja dalam } \\
\text { Bahasa Indonesia }\end{array}$ & $\begin{array}{c}\text { Kata kerja dalam } \\
\text { Bahasa Jawa }\end{array}$ & $\begin{array}{l}\text { Kata kerja dalam } \\
\text { Bahasa Indonesia }\end{array}$ \\
\hline Ngajak & Ajak & Kekeklek & Tertelan \\
\hline Ngajar & Ajar & Kesapu & Tersapu \\
\hline Jikok & Ambil & Keangkat & Terangkat \\
\hline Terke & Antar & Kepangan & Termakan \\
\hline Tangi & Bangun & Kecokot & Tergigit \\
\hline Mbakar & Bakar & Kekombe & Terminum \\
\hline Ngekei & Beri & Dipangan & Dimakan \\
\hline Mbongkar & Bongkar & Diombe & Diminum \\
\hline Carup & Campur & Dikeduk & Digali \\
\hline Nyolong & Curi & Diuncal & Dilempat \\
\hline Menging & Cegah & Dijak & Diajak \\
\hline Cepet & Cepat & Dijikok & Diambil \\
\hline Teko & Dating & Diterke & Diantar \\
\hline Rungokne & Dengar & Digolek i & Dicari \\
\hline Ngagabung & Gabung & Dicolong & Dicuri \\
\hline Nggesek & Gesek & Digowo & Dibawa \\
\hline Nggantung & Gantung & Dijikokne & Diambilkan \\
\hline Guleng & Guling & Gowokno & Bawakan \\
\hline Apos & Hapus & Kenterne & Hanyutkan \\
\hline Pepet & Himpit & Tulesne & Tuliskan \\
\hline Irop & Hirup & Jabuti & Cabuti \\
\hline Sedot & Hisap & gebuk i & Pukuli \\
\hline Bondo & Ikat & Tulisi & Tulisi \\
\hline Ires & Iris & Jikoklah & Ambilah \\
\hline Njogo & Jaga & Woconen & Bacalah \\
\hline Njahet & Jahit & Pangannen & Makanlah \\
\hline Dalan & Jalan & Ombenen & Minumlah \\
\hline Ceblok & Jatuh & Mbocokne & Membacakan \\
\hline Uncal & Lempar & Mbalekne & Mengembalikan \\
\hline Lewat & Lewat & Nyeblokne & Menjatuhkan \\
\hline Njalok & Minta & Mangan-mangan & Makan-makan \\
\hline Mutah & Muntah & Omben-omben & Minum-minum \\
\hline Munggah & Naik & Mblayu-mblayu & Lari-lari \\
\hline Nari & Nari & Playon-playon & Berlari-lari \\
\hline Enggo & Pakai & Cerito-cerito & Bercerita-cerita \\
\hline Pekso & Paksa & Obah-obah & Bergerak-gerak \\
\hline Cekel & Pegang & Mlaku-mlaku & Berjalan-jalan \\
\hline Lungo & Pergi & Salam-salaman & Bersalam-salaman \\
\hline Grayah & Raba & Nguyu-nguyu & Tertawa-tawa \\
\hline Roso & Rasa & Pringas-pringis & Tersenyum-senyum \\
\hline Numbur & Tabrak & Ngolek-golek i & Mencari-cari \\
\hline Takok & Tanya & Mboco-mboco & Membaca-baca \\
\hline Turu & Tidur & Nules-nules & Menulis-nulis \\
\hline Tulong & Tolong & Njoget-njoget & Menari-nari \\
\hline Njoget & Menari & Ditarek-tarek & Ditarik-tarik \\
\hline Nyanyi & Menyanyi & Diterke & Diantarkan \\
\hline Ngrabuk & Memupuk & Dibalekne & Dikembalikan \\
\hline Njotos & Memukul & Nuleske & Menuliskan \\
\hline Nguyu & Tertawa & Mlayukne & Melarikan \\
\hline Ceblok & Terjatuh & Ngrapikne & Merapikan \\
\hline
\end{tabular}




\begin{tabular}{|c|c|c|}
\hline No & Kalimat dalam Bahasa Jawa & Kalimat dalam Bahasa Indonesia \\
\hline 1 & Aku biasane mlaku. & Saya biasa berjalan kaki. \\
\hline 2 & Jajal ngoco disek! & Cobalah bercermin dahulu! \\
\hline 3 & Ojo ngidu neng kene. & Jangan berludah di sini! \\
\hline 4 & Sesok de e mlaku-mlaku jarene. & Besok di jalan-jalan, katanya. \\
\hline 5 & Azam belajar nules & Azam belajar menulis. \\
\hline 6 & Mamak nyilikne klambi & Ibu mengecilkan baju. \\
\hline 7 & Bibik dodolan neng pasar. & Bibik berjualan di pasar. \\
\hline 8 & Wong iku mlayu keweden. & Orang itu berlari ketakutan. \\
\hline 9 & Sopo seng dodolan neng pasar? & Siapa yang berjualan di pasar? \\
\hline 10 & Sopo seng nebang uwet? & Siapa yang menebang pohon? \\
\hline 11 & Mamak orak masak. & Ibu tidak memasak. \\
\hline 12 & Bocah kae nanges mergo ceblok. & Anak itu menangis karena terjatuh. \\
\hline 13 & Wong kae mbakar ladange. & Orang itu membakar ladangnya. \\
\hline 14 & Sopo seng tuku omah kae? & Siapa yang membeli rumah itu? \\
\hline 15 & Wong kae tuku sego. & Orang itu membeli nasi. \\
\hline 16 & Lelek nyelok anak e. & Paman memanggil anaknya. \\
\hline 17 & Ojo menek uwet! & Jangan memanjat pohon! \\
\hline 18 & Gades kae lincah njoget. & Gadis itu pandai menari. \\
\hline 19 & Bapak mbakar kertas. & Ayah membakar kertas. \\
\hline 20 & Adek ngrungokne simbah cerito. & Adik mendengar nenek bercerita. \\
\hline 21 & De e ngeterne sego go bapak e. & Dia mengantarkan nasi untuk ayahnya. \\
\hline 22 & De e ndongakne keselametan anak e. & Dia mendoakan keselamatan anaknya. \\
\hline 23 & Wong kae nurokne anak e. & Orang itu menidurkan anaknya. \\
\hline 24 & Adek mboco buku cerito. & Adik membaca buku cerita. \\
\hline 25 & Nengdi mamak ngajar? & Dimana ibu mengajar? \\
\hline 26 & Mamak mbungkus sego. & Ibu membungkus nasi. \\
\hline 27 & Mamak nukokne klambi adek. & Ibu membelikan baju adik. \\
\hline 28 & Sopo seng nguncal pitek? & Siapa yang melempar ayam? \\
\hline 29 & Sopo seng ngeterke sego? & Siapa yang mengantarkan nasi? \\
\hline 30 & Aku keturon neng pangkuan e mamak! & Aku tertidur di pangkuan ibu! \\
\hline 31 & Mikerlah seng apik! & Berfikirlah dengan baik! \\
\hline 32 & Keknolah duet kuwi neng dekne! & Berikalah uang itu padanya! \\
\hline 33 & Bocolah buku kae! & Bacalah buku itu! \\
\hline 34 & Ngomonglah karo aku! & Bicaralah kepadaku! \\
\hline 35 & Takoklah karo de e! & Bertanyalah kepadanya! \\
\hline 36 & Kekno buku kae! & Berikan buku itu! \\
\hline 37 & Klambi kae dijaet mamak. & Baju itu dijahit ibu. \\
\hline 38 & Kembang kae ditandur neng njero pot. & Bunga itu ditanam dalam pot. \\
\hline 39 & Kopi dipepe. & Kopi dijemur. \\
\hline 40 & Buah kae dipangan adek. & Buah itu dimakan adik. \\
\hline 41 & Opo seng dijaet mamak? & Apa yang dijahit ibu. \\
\hline 42 & Opo seng dipangan adek? & Apa yang dimakan adik. \\
\hline 43 & Nengdi kembang ditandur? & Di mana bunga ditanam? \\
\hline 44 & Adek ceblok seko uwet. & Adik terjatuh dari pohon. \\
\hline 45 & De e ketok sumringah seneng. & Dia terlihat sangat bahagia. \\
\hline 46 & Adek ngidek paku. & Adik terinjak paku. \\
\hline 47 & Dee mangan-mangan neng ngisor uwet. & Dia makan-makan di bawah pohon. \\
\hline 48 & De e liburan mlaku-mlaku neng Bali. & Dia liburan jalan-jalan ke Bali \\
\hline 49 & Tinggalno sediluk. & Tinggalkan sebentar. \\
\hline 50 & Jikokno buku neng nduwur mejo! & Ambilkan buku di atas meja! \\
\hline
\end{tabular}

\section{PENUTUP}

Berdasarkan pada hasil penelitian yang telah dilakukan terhadap delapan informan di Desa Srimulyo Kecamatan Belitang Mulya yang mewakili empat status sosial di antaranya pedagang, PNS, guru dan petani, dapat diperoleh simpulan bahwa terdapat tiga bentuk verba yaitu: (1) makna verba berafiks, di mana verba berafiks berjumlah tujuh (2) makna reduplikasi verba, di mana makna reduplikasi verba berjumlah enam dan (3) makna komposisi verba, di mana makna komposisi verba berjumlah dua. 
SEMANTIK DAN APLIKASINYA PADA STRUKTUR KALIMAT ... $\mid 43$

Dari ketiga bentuk makna verba tersebut diperoleh seratus kata kerja dan lima puluh kalimat yang menggunakan kata kerja mengenai semantik verba bahasa Jawa. Semantik verba bahasa Jawa sama dengan semantik verba bahasa Indonesia. Hanya saja terjadi perubahan pada fonemnya.

\section{DAFTAR PUSTAKA}

Addhintheas. Judul Jurnal. Metode Penelitian Deskriptif, Tahun 2013 No 04/ Juni - Oktober 2013, (diakses 5 Mei 2020).

Chaer, Abdul. 2015. Psikolinguistik Kajian Teriorik. Jakarta: Rineka Cipta.

Chaer, Abdul. 2012. Linguistik Umum. Jakarta: Rineka Cipta.

Chaer, Abdul. 2007. Kajian Bahasa Struktur Internal, Pemakaian, dan Pembelajaran. Jakarta: Rineka Cipta.

Chaer, Abdul. 2009. Pengantar Semantik Bahasa Indonesia. Jakarta: Rineka Cipta.

Chaer, Abdul. 2011. Tata Bahasa Praktis Bahasa Indonesia. Jakarta: Rineka Cipta

HsfBot. Judul Jurnal. Metodologi Penelitian, Tahun 2017 (Diakses 5 Mei 2020)

KBBI. 2008. Jakarta: Gramedia Pustaka Utama.

Mahsun. 2011. Metode Penelitian Bahasa Tahapan Strategi, Metode, dan Tekniknya (Edisi Revisi). Jakarta: Raja Grafindo Persada.

Muhammad, 2016. Metode Penelitian Bahasa. Jogyakarta: Ar-Ruzz Media.

Pateda, Mansoer. 2004. Semantik Leksikal Edisi II. Jakarta: Rineka Cipta.

Rakim. Judul jurnal, Jurnal Metode Penelitian, Tahun 2008 No.06/ Februari-September 2008, (diakses 5 Mei 2020)

Ullman, Stephen. 2011. Pengantar Semantik. Jogyakarta: Pustaka Pelajar.

Sugiono. 2016. Metode Penelitian Kuantitatif, Kualitatif, dan R\&D. Bandung: Alfabeta. 